\title{
Entre lo natural y lo social. Las crisis de subsistencia a fines de la Edad Media castellana (Ávila, 1500-1504)*
}

\author{
Between natural and social causes. Subsistence crises \\ in Late Medieval Castile (the case of Ávila, 1500-1504)
}

\author{
Octavio Colombo**
}

\begin{abstract}
RESUMEN
El objetivo de este trabajo es presentar algunas reflexiones sobre las crisis de subsistencia en la Baja Edad Media castellana. En la primera parte se exponen los enfoques más relevantes sobre el tema, que tienden a presentar una dicotomía en la elección de causas naturales o sociales para la explicación de la crisis. Luego se presentan algunos comentarios generales que ponen en cuestión la rigidez de estos presupuestos.

Por último, se estudia la evolución de la coyuntura comprendida entre 1500 y 1504 en Ávila y su Tierra, con el objeto de identificar la forma en que distintos factores inciden en los orígenes de la crisis. Este análisis nos conduce a concluir en la necesidad de desarrollar una perspectiva más amplia, que integre tanto las causas naturales como las sociales y políticas en una conceptualización más rigurosa de la totalidad social.
\end{abstract}

\section{PALABRAS CLAVE}

Crisis de subsistencia, campesinado, Ávila.

\begin{abstract}
The aim of this study is to present some thoughts on the subsistence crisis in Castile at the end of the Middle Ages. In part one, we will outline the most important approaches in the analysis of this issue, which often manifest a dichotomy between the natural and the social causes of subsistence crises. Following that, we will advance certain arguments that question the rigidity of these assumptions. Finally, we will analyze the evolution of the situation between 1500 and 1504 in the town and country of Ávila, in order to identify the way in which different factors have a bearing on the origin of each crisis. This study concludes that a wider perspective is needed, including natural as well as social and political causes in a more rigorous conceptualization of the social reality.
\end{abstract}

\section{KEY WORDS}

Subsistence crisis, Peasantry, Ávila.

* Fecha de recepción del artículo: 2011-12-9. Fecha de aceptación del artículo: 2012-3-12.

** Universidad de Buenos Aires-CONICET. C.e.: octacolombo@ hotmail.com 


\section{INTRODUCCIÓN}

El objetivo de este trabajo es aportar algunas reflexiones en torno a la problemática de las crisis de subsistencia en la Baja Edad Media castellana. Como veremos enseguida, si bien no se trata de un objeto en absoluto novedoso, el tema atrae actualmente una creciente atención por parte de los especialistas. Tal vez no sea ajena a esta situación la preocupación contemporánea en torno a la cuestión medioambiental, como así también la persistencia de hambrunas localizadas en un mundo donde el incremento de la productividad haría esperar la superación definitiva de tales coyunturas.

De manera esquemática, puede decirse que las crisis de subsistencia han sido abordadas desde tres perspectivas o paradigmas distintos. El primero, con el cual el medievalismo está altamente familiarizado, es el que se inspira en la obra de Malthus. Su idea central es que las crisis se originan en una caída de la producción, cuya causa profunda se encuentra en un crecimiento demográfico excesivo en relación con la capacidad productiva de la sociedad. En conjunción con otros supuestos, como la teoría ricardiana del rendimiento decreciente de las tierras marginales, el agotamiento de los suelos y la fragmentación de las tenencias por la sobrepoblación, el modelo malthusiano permitía explicar cómo el equilibrio entre población y recursos llegaba a un punto crítico en el cual cualquier fenómeno accidental podía desencadenar la catástrofe demográfica ${ }^{1}$. Las hambrunas, entonces, actúan como un fenómeno regulador del tamaño de la población frente a la capacidad de la sociedad para producir alimentos. Incluso en una formulación teóricamente menos rígida, esto es, que no implique suscribir la supuesta tendencia biológica de la humanidad a rebasar periódicamente sus posibilidades materiales de reproducción, la concentración del enfoque malthusiano en los rendimientos productivos como causa de la crisis resultaba especialmente atractiva para el estudio de sociedades preindustriales que presentan una fuerte dependencia de las fluctuaciones de las cosechas por razones climáticas aleatorias.

Frente a este enfoque de las crisis de subsistencia como resultado del fracaso en la producción de recursos, el economista Amartya Sen desarrolló a principios de la década de 1980 la perspectiva conocida como el entitlement approach. Basándose en el estudio de cuatro casos de hambrunas contemporáneas en países subdesarrollados, Sen sostuvo que estas coyunturas no se encuentran necesariamente vinculadas a una reducción objetiva en la disponibilidad de bienes de subsistencia, sino a la incapacidad social de los sujetos para acceder a ellos. Dicho en otros términos, las crisis de subsistencia deben entenderse, no como el resultado de un fracaso en la producción de alimentos, sino como el resultado de una

\footnotetext{
1 Entre los medievalistas, la formulación clásica de este enfoque es la de POSTAN, M., «Los fundamentos económicos de la sociedad medieval», en IDEM, Ensayos sobre agricultura y problemas generales de la economía medieval, Madrid, Siglo XXI, 1981. BOIS, G., Crise du féodalisme, Paris, Presses de la Fondation Nationale des Sciences Politiques, 1976, postula una dinámica similar pero donde el factor desencadenante es el aumento de la presión tributaria.
} 
quiebra de los derechos de acceso o de apropiación de los bienes por parte de los sectores más vulnerables de la sociedad — paradójicamente, en muchos casos, aquéllos que producen de forma directa los bienes de subsistencia².

La importancia fundamental de esta perspectiva consiste en otorgar a las crisis de subsistencia un contenido histórico tradicionalmente oscurecido por el enfoque malthusiano. En efecto, mientras este último indicaba como causa excluyente la limitación natural (en el sentido de ecológica) de la oferta de alimentos, el entitlement approach se basa en una concepción amplia de los derechos sociales de acceso a la riqueza, tanto en lo que hace a la esfera de la producción como de la distribución ${ }^{3}$. Sen no niega, por cierto, que la reducción de la oferta sea una causa posible de la crisis, pero su análisis se concentra en demostrar que no se trata de un factor necesario, ni siquiera habitual. Aunque esta propuesta interpretativa, como ya hemos señalado, fue concebida para el estudio de economías contemporáneas altamente mercantilizadas, se trata de una visión mucho más compleja de las causas y repercusiones del fenómeno de la carestía que enfatiza las condiciones sociales - antes que naturales - de la coyuntura y que ya ha atraído la atención de los historiadores abocados al estudio de sociedades preindustriales.

En los últimos años, algunos autores han propuesto un tercer enfoque sobre el problema de las crisis de subsistencia. Frente a la perspectiva de Sen, que esencialmente remite al proceso económico global de las hambrunas, Devereux sostiene la necesidad de atender a los factores políticos en la explicación del origen de la coyuntura ${ }^{4}$. Las medidas gubernamentales, los conflictos civiles o la guerra son indicados como factores fundamentales en los análisis de muchas de las «nuevas hambrunas", registradas en los últimos veinte años. En el mismo sentido, la incapacidad o la negativa de los poderes públicos para prevenir o dar respuestas satisfactorias a la carestía y, por consiguiente, su responsabilidad en permitir que ésta se transforme en hambruna, aparecen como determinantes. Esta propuesta puede entenderse como una profundización de la perspectiva socio-histórica del entitlement approach que trasciende los límites del análisis económico del fenómeno, incorporando situaciones en las cuales la crisis no es el resultado de un fracaso, sea en la producción o en el acceso a los recursos, sino el producto —por acción u omisión- de medidas políticas determinadas. Si bien este enfoque, aún en formación, se ha desarrollado a partir del estudio de las crisis más recientes que se registraron en el mundo subdesarrollado, especialmente en África, Devereux sostiene la necesidad de indagar su utilidad retrospectiva para el análisis de situaciones históricas ${ }^{5}$.

Consideradas globalmente, estas tres grandes perspectivas conforman la herencia analítica fundamental sobre el problema de las carestías y hambrunas.

\footnotetext{
2 SEN, A., Poverty and Famines. An Essay on Entitlement and Deprivation, New York, Oxford University Press, 1981.

3 IDEM, p. 6.

4 DEVEREUX, S., «Introduction: from "old famines" to "new famines" », en IDEM (ed.), The New Famines. Why famines persist in an era of globalization, London and New York, Routledge, 2007.
} 
Como veremos enseguida, la problemática que aborda cada una de ellas no es ajena a la historiografía sobre las crisis de subsistencia en el feudalismo, aunque ésta no se haya desarrollado de una forma tan modélica como nuestra esquemática presentación anterior podría inducir a pensar. Ello se debe, en nuestra opinión, a que el registro histórico, aun cuando sea relativamente escaso y parcial, presenta una riqueza de elementos que resulta imposible encuadrar en un paradigma unívoco. En este trabajo haremos algunos comentarios generales sobre las características de las economías campesinas concejiles para luego centrarnos en la discusión de los orígenes de la carestía de principios del siglo XVI en el obispado de Ávila. Aspiramos con ello a contribuir a la discusión historiográfica actual, en especial a lo que parece perfilarse como una dicotomía entre lo natural y lo social cuya utilidad analítica y pertinencia conceptual resultan cuestionables, con el objeto de promover la profundización de los estudios sobre el tema.

\section{LA HISTORIOGRAFÍA}

En rigor, debe señalarse que aun antes de que el paradigma malthusiano para la interpretación de las carestías fuera formalmente objetado por Amartya Sen, la historiografía ya había establecido que tales coyunturas presentan una conjunción de factores de distinta índole. Los aportes clásicos sobre el tema provienen fundamentalmente de los historiadores dedicados al estudio de la Europa Moderna, donde la disponibilidad de series relativamente prolongadas de precios permitió un estudio cuantitativo de las fluctuaciones de corta duración ${ }^{6}$. Ernest Labrousse elaboró el modelo más sólido y difundido, a partir del cual el concepto de «crisis de tipo antiguo» pasó a formar parte del lenguaje común de los historiadores $^{7}$. En su análisis, si bien el movimiento se inicia con una reducción del volumen de la cosecha, se demuestra la inexistencia de una relación inmediata o proporcional entre las fluctuaciones de los precios y la productividad agraria. El movimiento global de la coyuntura, por lo tanto, sólo puede comprenderse a partir de las características históricas de la estructura social ${ }^{8}$. En especial, la transformación de la crisis de subproducción agrícola en una crisis de subconsumo en el sector industrial manifiesta la forma peculiar en que actúa la esfera de la circulación en la evolución de la coyuntura, ejemplificando la temprana atención que brindó la historiografía a estos aspectos de las crisis cortas $^{9}$.

5 IDEM, p. 13.

6 Aunque también debe señalarse que las series de precios no constituyen, como a veces se supone, índices fiables de la evolución de los rendimientos agrarios; WRIGLEY, E. A., «Algunas reflexiones sobre la producción y los precios del grano en las economías preindustriales», en IDEM, Gentes, ciudades y riqueza. La transformación de la sociedad tradicional, Barcelona, Crítica, 1992.

7 LABROUSSE, E., Fluctuaciones económicas e historia social, Madrid, Tecnos, 1973.

8 IDEM, pp. 191 y 317.

9 IDEM, p. 220. 
Otros autores aportaron indicios en direcciones similares. Abel, por ejemplo, intentó discriminar el impacto que tenía una reducción de los rendimientos agrícolas en los distintos sectores del campesinado, lo que explica cómo la diferenciación social mediatiza las consecuencias de la crisis agraria ${ }^{10}$. Kula, por su parte, dedicó el capítulo más importante de su Teoría económica del sistema feudal al estudio de la dinámica de corto plazo, aplicando las ideas de Chayanov en relación al comportamiento «inverso» del campesino ante las fluctuaciones de los precios ${ }^{11}$. La historiografía hispánica también cuenta con el clásico trabajo de Gonzalo Anes sobre el período moderno, de Palop sobre la Valencia del siglo XVIII o con el estudio de Bartolomé Yun sobre la crisis de subsistencia en Córdoba a principios del siglo XVI, entre otros ${ }^{12}$. Pero más allá de esta escueta enumeración, lo que nos interesa destacar es que aun en el contexto de predominio del enfoque malthusiano, las investigaciones no se habían limitado a un modelo lineal y simplista basado en la caída de los rendimientos, sino que habían tendido a incorporar otros elementos que complejizan la coyuntura.

Los aportes del medievalismo sobre la materia son más exiguos. Algunos hispanistas aportaron interesantes estudios de caso, poniendo también en evidencia la conjunción de factores que presentan las crisis de subsistencia: a las alteraciones climáticas que provocan la caída de los rendimientos deben agregarse las guerras, devaluaciones, aumentos de tributo y brotes epidémicos, fenómenos entre los cuales la relación de causalidad, si es que existe, en ningún caso resulta obvia o lineal ${ }^{13}$. Aunque importantes, estas contribuciones no alcanzan para refutar un juicio global pesimista: «conocemos aún mal las múltiples crisis agrarias y de subsistencia que afectaron a las regiones y ciudades de la Península Ibérica a lo largo de la Edad Media, las causas que las desencadenaron y sus conse-

10 ABEL, W., La agricultura: sus crisis y coyunturas. Una historia de la agricultura y la economía alimentaria en Europa Central desde la Alta Edad Media, México, FCE, 1986.

${ }_{11}$ KULA, W., Teoría económica del sistema feudal, Buenos Aires, Siglo XXI, 1974. CHAYANOV, A., La organización de la unidad económica campesina, Buenos Aires, 1974.

12 ANES ÁlVAREZ, G., Las crisis agrarias en la España Moderna, Madrid, Taurus, 1974; PALOP, J. M., Hambre y lucha antifeudal. Las crisis de subsistencias en Valencia (Siglo XVIII), Madrid, Siglo XXI, 1977; YUN CASALILLA, B., Crisis de subsistencia y conflictividad social en Córdoba a principios del siglo XVI: Una ciudad andaluza en los comienzos de la Modernidad, Córdoba, Publicaciones de la Excma. Diputación Provincial, 1980.

${ }_{13}$ Algunos ejemplos relevantes adicionales donde se trata directa o indirectamente la problemática para el período medieval tardío son: AGUADÉ NIETO, S., «Crisis de subsistencia, rentas eclesiásticas y caridad en la Castilla de la segunda mitad del siglo XV», En la España Medieval, no 2: Estudios en memoria del Prof. Salvador de Moxó, I, 1982; SÁNCHEZ BENITO, J. M., "Crisis de abastecimiento y administración concejil. Cuenca, 1499-1509», En la España Medieval, no 14, 1991; GONZÁLEZ JIMÉNEZ, M., «Las crisis cerealistas en Carmona a fines de la Edad Media», Historia. Instituciones. Documentos, no 3, 1976; GONZÁLEZ GÓMEZ, A., «Producción y precios de cereales en Trigueros (Huelva), 14501512», En la España Medieval, no 1, 1980; BONACHÍA HERNANDO, J. A., «Abastecimiento urbano, mercado local y control municipal. La provisión y comercialización de la carne en Burgos (siglo XV)», Espacio, Tiempo y Forma. Serie III. Historia Medieval, V, 1992; CASADO ALONSO, H., «Producción agraria, precios y conyuntura económica en las diócesis de Burgos y Palencia a fines de la Edad Media», Studia Historica. Historia Medieval, no 9, 1991. 
cuencias directas e indirectas sobre la economía, la sociedad y la demografía» ${ }^{14}$. Pero esta afirmación proviene de la compilación de Oliva Herrer y Benito Monclús publicada por la Universidad de Sevilla en 2007, contribución bibliográfica que se ubica plenamente en el contexto del debate historiográfico actual sobre las carestías.

En efecto, en el curso de los últimos años puede registrarse la recepción historiográfica, tardía pero vigorosa, de los planteamientos de Amartya Sen para el estudio de las crisis de subsistencia en la sociedad europea preindustrial. La compilación de 2007 que acabamos de mencionar, centrada en el mundo rural hispánico pero que también incluye aportes de especialistas de otras áreas del continente, manifiesta la preocupación actual de los historiadores por dar cuenta de la complejidad del fenómeno de la carestía. Aun cuando, como hemos dicho, los estudios anteriores ya habían registrado la confluencia de diversos factores en la coyuntura, el abandono consciente del modelo malthusiano de la crisis, con su relación lineal entre problemas climáticos, malas cosechas y hambrunas, encuentra en las reflexiones de Sen un atractivo foco de referencia teórica para la comprensión del fragmentario material empírico disponible. El cambio de tendencia es auspicioso y estimula una visión más amplia del fenómeno, de lo que constituye un buen ejemplo el estudio de Sánchez Benito sobre la política mercantil del concejo conquense en el siglo $\mathrm{XV}^{15}$. Por cierto, la nueva perspectiva historiográfica transciende al medievalismo hispánico, como puede verse en algunas de las contribuciones al número especial de la Economic History Review aparecido en 2008 sobre el tema ${ }^{16}$.

El carácter relativamente tardío de la difusión del entitlement approach en nuestra disciplina (recuérdese que la publicación original de Poverty and Famines es del año 1981) constituye, en nuestra opinión, un ejemplo de cómo la evolución historiográfica no consiste en un mero reflejo frente a la aparición de nuevas teorías sociales, sino que combina los aportes provenientes de otras áreas del conocimiento con sus propias tendencias de desarrollo interno. En efecto, en las últimas dos décadas se ha operado un cambio sustancial en nuestra concepción de la economía y la sociedad medieval, lo que Dyer no duda en denominar como una «nueva Edad Media» por contraste con la visión pesimista que había predominado hasta entonces ${ }^{17}$. En gran medida por influencia del enfoque malthusiano, pero también presente en otras elaboraciones - como en el influyente artículo de Robert

14 OLIVA HERRER, H. R., y BENITO I MONCLÚS, P. (coords.), Crisis de subsistencia y crisis agrarias en la Edad Media, Sevilla, Secretariado de Publicaciones de la Universidad de Sevilla, 2007, «Presentación», p. 11.

15 SÁNCHEZ BENITO, J. M., «Coyuntura económica y política mercantil urbana (Cuenca, siglo XV)», Edad Media. Revista de Historia, № 9, 2008.

${ }_{16}$ «Special Issue: Feeding the masses: plenty, want and the distribution of food and drink in historical perspective», Economic History Review, vol. 61, Issue Supplement 1, 2008.

17 DYER, C., An Age of Transition? Economy and Society in England in the Later Middle Ages, Oxford, Clarendon Press, 2005. 
Brenner sobre la estructura agraria ${ }^{18}$ - la concepción dominante había enfatizado la tendencia al estancamiento y la imposibilidad de superar los férreos límites estructurales que afectaban a la sociedad feudal. En este contexto, como es lógico, la interpretación más difundida sobre las carestías no podía ser otra que la concentrada en el fracaso de la producción de bienes de subsistencia.

Desde la década de 1990 en adelante, por contraste, la historiografía económica ha ido consolidando una visión dinámica del mundo medieval, con especial énfasis en los efectos positivos que habría tenido el incremento de la comercialización y la expansión de los mercados locales y regionales ${ }^{19}$. Hubo que esperar a que este enfoque de perfil smithiano madurara y adquiriera una relativa consistencia para que la propuesta del entitlement approach se tornara atractiva y pudiera ser coherentemente incorporada al discurso del medievalismo. Como veremos enseguida, esta lógica interna del desarrollo historiográfico no sólo permite comprender el cuándo de esta asimilación, sino también el cómo, es decir, el sesgo interpretativo de la misma.

Pero muy recientemente también ha comenzado a manifestarse una reacción a este enfoque de las crisis. La crítica no se dirige, como hemos visto que ocurre entre los analistas de las hambrunas contemporáneas, al carácter todavía demasiado económico del modelo de Sen, sino por el contrario a su carácter demasiado social, esto es, al relegamiento de la incidencia de lo natural en la historia. Dos artículos de reconocidos investigadores aparecidos en 2010 expresan esta nueva tendencia: nos referimos al estudio de Hoyle sobre la hambruna de 1622-1624 en Lancashire y, especialmente, al planteamiento general de B. Campbell, eminente especialista en la historia de la agricultura medieval inglesa, sobre el «protagonismo histórico» de la naturaleza ${ }^{20}$. Esta vuelta al enfoque de las carestías como originadas en el fracaso de la producción no supone, sin embargo, una reivindicación acrítica de los presupuestos malthusianos sobre el desbalance entre población y recursos, sino un intento por calibrar de forma más ajustada la incidencia en el devenir histórico de los límites impuestos por las condiciones ecológicas, congruente con la conciencia política actual en cuanto al deterioro de las mismas como resultado del desarrollo de la producción capitalista moderna.

18 BRENNER, R., «Estructura de clases agraria y desarrollo económico en la Europa preindustrial», en ASTON, T. H., y PHILPIN, C. H. E. (eds.), El debate Brenner. Estructura de clases agraria y desarrollo económico en la Europa preindustrial, Barcelona, Crítica, 1988.

19 La llamada «tesis de la comercialización» fue especialmente difundida en la historiografía inglesa por BRITNELL, R., The Commercialisation of English Society, 1000-1500, Cambridge, Cambridge University Press, 1993. Véase al respecto HATCHER, J., y BAILEY, M., Modelling the Middle Ages. The History and Theory of England's Economic Development, Oxford, Oxford University Press, 2001, Cap. 3; DYER, Ch. y SCHOFIELD, Ph., «Estudios recientes sobre la historia agraria y rural medieval británica», en Alfonso, I. (ed.), La historia rural de las sociedades medievales europeas, Valencia, PUV, 2008.

20 HOYLE, R. W., «Famine as agricultural catastrophe: the crisis of 1622-24 in east Lancashire», Economic History Review, vol. 63, n 4, 2010. CAMPBELL, B., «Nature as historical protagonist: environment and society in pre-industrial England», Economic History Review, vol. 63, nํ2, 2010. 
En suma, la coyuntura actual de la disciplina parece más próxima a seguir indagando la pertinencia del entitlement approach antes que a dar el paso propuesto por Devereux hacia una interpretación abiertamente política de las causas de las hambrunas (lo que, bien visto, debemos apreciar positivamente como muestra del carácter reflexivo de la recepción historiográfica de los paradigmas propuestos por otras ciencias sociales). En sus términos extremos la discusión oscila, entonces, entre atribuir las causas de las carestías o bien a lo natural, asociado al ámbito de la producción y al peso determinante de los fenómenos climáticos en ella, o bien a lo social, entendido como el ámbito de la distribución y circulación de la riqueza. Mientras que la historiografía anterior resaltaba espontáneamente, a veces incluso de manera descriptiva, la conjunción de diversos factores en la coyuntura, el paulatino impacto de las modelizaciones teóricas amenaza con introducir una tendencia dicotómica, aunque conceptualmente más consciente. Sobra aclarar que ambos aspectos, esto es, tanto el apego a la complejidad de lo concreto como la búsqueda de una mayor consistencia analítica, debieran ser rescatados.

\section{LA ECONOMÍA CONCEJIL Y LAS CRISIS: APROXIMACIÓN GENERAL}

En esta perspectiva, ante todo es necesario indagar los fundamentos de la dicotomía planteada. La identificación de la producción con el ámbito de lo natural, es decir, como exclusiva o principalmente determinada por factores medioambientales, es una suposición demasiado unilateral y que debe ser relativizada. No sólo las técnicas y formas organizativas de la producción constituyen obviamente características históricas; también las nociones mismas de subsistencia y excedente lo son. Que un producto bruto de magnitud determinada permita o no la subsistencia de los productores, la repetición del ciclo productivo y el abastecimiento adecuado del mercado es una cuestión que no sólo depende de la magnitud absoluta del aquél, sino también de las condiciones sociales de su producción. Veamos un ejemplo: el concejo de Carmona afirma en la década de 1470, en el contexto de una coyuntura crítica, que sacadas las rentas de los diesmos de las iglesias e clérigos e de las heredades e bueyes, que va todo a esa çibdad [de Sevilla], non es posyble de lo que queda esta villa ser proveyda ${ }^{21}$. Frente a esto no es posible separar de modo excluyente los factores naturales y sociales en el origen de la crisis o, al menos, no es posible atribuir la hambruna únicamente a la caída de los rendimientos agrarios: lo que sabemos es que la subsistencia queda comprometida luego de la deducción de las rentas. Esto es válido aun cuando se reconozca abiertamente la reducción de los rendimientos productivos a causa de alteraciones climáticas. En 1467 otro documento del mismo lugar informa que por la grand mengua de la cosecha... non avemos nin cogemos pan de que sola mente

21 Citado en GONZÁLEZ JIMÉNEZ, M., «Las crisis cerealistas en Carmona...», p 288.

22 IBÍDEM. 
paguemos las rentas nin avn la symiente que sembramos ${ }^{22}$. En definitiva, si el tributo feudal constituye una relación de producción es porque determina las características sociales de ésta: en el caso citado, que la subsistencia del campesino aparezca como la magnitud residual una vez satisfecha la apropiación señorial.

Las relaciones feudales no sólo condicionan la apropiación de los medios de producción y por tanto del producto, sino también qué se produce. En 1504, en medio de la crisis de subsistencias de la que hablaremos más adelante, el lugar de Riofrío recibió un conjunto de migrantes de la comarca que se instalaron allí y labraron un alijar utilizado para pastos. Su desplazamiento y su condición de desposeídos, sin embargo, no era consecuencia de la carestía que arreciaba en la zona, sino del doble efecto de la apropiación privada y la orientación ganadera de los propietarios de la tierra:

a cavsa que los dueños de los heredamientos tienen fechas dehesas sus términos e poniéndoles encresçidas rrentas et que el pan que cogían non bastava para les pagar e que los términos a él comarcanos son de personas particulares donde non pueden labrar por pan, porque son dehesas de pasto e non de lavor ${ }^{23}$.

No se trata, por lo tanto, de negar la importancia de lo natural y su impacto sobre un sistema productivo fuertemente dependiente de las variaciones meteorológicas (lo cual en sí mismo es un rasgo histórico), pero sí de retomar lo que dijeran P. Vilar y E. P. Thompson en cuanto a que lo importante es la respuesta social a la crisis, la reacción histórica ante la naturaleza ${ }^{24}$. Y esa reacción histórica no es externa al ámbito de la producción, sino que está inscrita en ella en la medida en que la propiedad feudal de los medios de producción se traduce en una jerarquía de derechos de apropiación sobre el producto. Esto es lo que denuncian los pecheros de Ciudad Rodrigo en 1455 cuando exigen que el grano sea traído para provisión de la villa porquel más pan es en poder de los regidores, ansý de rentas que tienen arrendadas conmo de sus heredades ${ }^{25}$. En definitiva, que una cosecha inferior a la media se traduzca en una crisis de subsistencia o en una reducción de las rentas, por ejemplo, es algo que no puede deducirse meramente de la caída de los rendimientos.

Cabe señalar, en este sentido, que la asimilación historiográfica del entitlement approach ha tendido a ser demasiado unilateral, exclusivamente centrada en subrayar los derechos de apropiación en la circulación, lo que suponía aceptar implí-

${ }^{23}$ DEL SER QUIJANO, G., Documentación Medieval Abulense en el Registro General del Sello, Vol. XXII (3-V-1504 a 23-XII-1504), Ávila, 2010, doc. 33, 5/7/1504, p. 88.

24 El carácter histórico del atraso económico juega un papel destacado en la interpretación de BRENNER, ob. cit. VILAR, P. «Reflexiones sobre la "crisis de tipo antiguo'. "Desigualdad de las cosechas" y "subdesarrollo"», en IDEM, Economía, Derecho, Historia. Conceptos y realidades, Barcelona, Ariel, 1983, p. 17. THOMPSON, E. P., La formación de la clase obrera en Inglaterra, Barcelona, Crítica, 1989, Tomo I, p. 215.

${ }_{25}$ MONSALVO ANTÓN, J. M., «Aspectos de las culturas políticas de los caballeros y los pecheros en Salamanca y Ciudad Rodrigo a mediados del siglo XV. Violencias rurales y debates sobre el poder en los concejos", Annexes des CLCHM, vol. 16, 2004, Apéndice Documental, p. 283. 
citamente la identificación de la producción con lo natural. Este sesgo interpretativo se comprende si recordamos que la recepción de este enfoque se dio en un momento en el cual el medievalismo prestaba creciente atención a los problemas de la comercialización y los mercados. Sin embargo, el propio Amartya Sen incluía en su modelo teórico los derechos de apropiación en la producción ${ }^{26}$, aunque ciertamente en sus análisis concretos no prestó a estos últimos una atención adecuada.

Los comentarios anteriores apuntan a destacar que el ámbito de la producción no puede considerarse como exclusivamente determinado por factores naturales. Pasemos ahora a comentar su relación con el ámbito de la circulación. Aun cuando una coyuntura de crisis determinada pueda tener un origen más o menos indiscutible en la caída de los rendimientos agrarios resultante de alteraciones climáticas, ni aun así los mecanismos de la distribución pueden considerarse en un papel totalmente pasivo. Que las formas de circulación del producto potencien o mitiguen los efectos de las variaciones climáticas es algo que pertenece al dominio de la creación histórica ${ }^{27}$. En los mercados campesinos del área concejil castellana, la reducción del excedente comercializable es mucho más brusca que la del volumen total de la producción, motivo por el cual las fluctuaciones de los precios amplifican los efectos negativos de las malas $\operatorname{cosechas}^{28}$. Las peticiones de las Cortes mencionan repetidamente la relación entre mal tiempo y suba de precios, una causalidad que debemos considerar como propia de la forma mercantil que adopta el producto ${ }^{29}$. En Sepúlveda se otorga moratoria de un año a tres vecinos que se endeudaron

de pan que los ovieron fiado en los años pasados afortunados, cargándoles cada una fanega de trigo a trezientos maravedís; e que, por los años ser tan caros e fuertes, a cabsa de se mantener a ellos e a sus mugeres e fijos e se non dexar peresçer de fanbre, se ovieron de adebdar de tal manera que ellos han quedado pobres e destruidos ${ }^{30}$.

El aprovechamiento especulativo de la carestía forma parte constitutiva de la dinámica real de la coyuntura, aún cuando el origen de ésta se encuentre en la es-

${ }^{26}$ En su terminología, «production-based entitlement»; SEN, Poverty and..., p. 2.

27 «Los seres humanos tienen una gran capacidad de adaptación y pueden crear instituciones sociales para compensar los caprichos del clima o de la geografía. Por ejemplo, en el siglo XVIII China disponía de graneros del Estado que dispensaban cereal en tiempos de necesidad, y mercados que movían el cereal desde las áreas con excedentes hasta las áreas con déficit», MARKS, R., Los orígenes del mundo moderno. Una nueva visión, Barcelona, Crítica, 2007, p. 306, nota 4.

${ }_{28}$ Hemos analizado esta cuestión con más detalle en COLOMBO, O., «La ley del valor en los mercados campesinos precapitalistas», Anales de Historia antigua, Medieval y Moderna, no 42, 2010.

${ }^{29}$... en este anno en questamos fue muy grant mortandat en los ganados, e otrosi la simiença muy tardia por el muy fuerte tenporal que ha fecho de muy grandes nieves e de grandes yelos, en manera quelas carnes son muy encarecydas e los omes non las pueden auer, e el pan e las carnes encarecen de cada dia, Cortes de los Antiguos Reinos de León y de Castilla, Real Academia de la Historia, Madrid, 1861-82 (en adelante: Cortes), tomo I, 1345, pet. 1, p. 484.

30 SÁEZ SÁNCHEZ, C., Colección diplomática de Sepúlveda II, 1076-1485, Segovia, 1991, doc. 170, 30/1/1480, p. 271; el precio es exorbitante, tal vez 5 ó 6 veces superior al normal. 
fera de la producción. A estas prácticas se oponen los controles políticos que implementan los concejos, y en ocasiones la propia monarquía, sobre la circulación - como tendremos ocasión de ver enseguida en un caso particular. La normativa sobre precios, las restricciones a la saca fuera del término concejil y, desde principios del siglo XVI, la creación de «pósitos» fueron algunas de las medidas más habituales para combatir la carestía y sus efectos disruptivos sobre el abastecimiento de los mercados locales. Por el momento basta con señalar que, antes que oponer producción y circulación como explicaciones alternativas de la crisis, el material empírico nos induce a preguntar cómo se interrelacionan entre sí.

La importancia de los mecanismos de circulación es aún mayor cuando encontramos estructuras concejiles cuya reproducción depende fuertemente del abasto externo. En Piedrahíta, por ejemplo, las autoridades locales explican que la villa es muy estéril de pan e no tiene de su cosecha para la quarta parte del año, $e$ no ay quien tenga pan de renta en la dicha villa, para lo vender, que le sobre de su mantenimiento ${ }^{31}$. En estas condiciones, el abasto local se garantiza porque tres vecinos de la villa que tienen pan de renta para vender de propiedades situadas fuera de la jurisdicción concejil lo mandan traer al mercado local, e otras ocho o diez personas que ay en la villa de conprar pan en el mercado de Peñaranda e dar por cada fanega diez maravedíes, porque ge lo traygan a esta villa ${ }^{32}$. En casos como este, donde queda claro el lugar prominente de unos pocos sujetos en el abasto de la villa, la posibilidad de que la escasez de viandas tenga su origen en problemas de la circulación se incrementa. Los conflictos entre distintas jurisdicciones suelen mostrar este punto débil de la reproducción comunal. Un caso que tuvo pronta resolución se originó a fines del siglo XIV entre el señorío de Huete, perteneciente a la reina de Castilla, y la villa de Cuenca. Como en el primero se había promulgado una ordenanza impidiendo la saca de pan, Cuenca hubo de elevar una queja explicando que su cosecha local era muy poco e que todo tienpo biven de acarreo, por lo cual era para ellos indispensable proveerse en la villa y tierra de Huete del pan que han meester para sus mantenimientos e provisiones ${ }^{33}$. Mombeltrán parece haber tenido menos éxito en un conflicto similar durante los primeros años de la década de 1420. Amparándose en una carta de Juan II donde se mandaba deshacer todos los vedamientos e defendimientos que impedían la libre circulación del pan entre los distintos lugares del reino, denuncia que los concejos de la región desconocen tal mandamiento y que han vedado e defendido la saca de pan, trigo e çevada e çenteno, por lo cual ellos no pueden obtener lo que necesitan ${ }^{34}$. A fines de 1423 los representantes de Mombeltrán presentan la misiva del monarca ante el

31 LUIS LÓPEZ, C., Colección Documental del Archivo Municipal de Piedrahíta (1372-1549), Ávila, 1987, doc. $61,16 / 5 / 1499$, p. 119.

${ }_{32}$ IBÍDEM; aclaremos que el precio de $10 \mathrm{mrs}$. corresponde al costo del transporte, no al del grano.

33 CHACÓN GÓMEZ-MONEDERO, F. A., Colección diplomática del concejo de Cuenca 1190-1417, Cuenca, 1998, doc. 168, 12/5/1399, p. 394.

${ }^{34}$ BARRIOS GARCÍA, A., CORRAL, F. L., RIAÑO PÉREZ, E., Documentación medieval del Archivo Municipal de Mombeltrán, Ávila, 1996 (en adelante: Mombeltrán), doc. 10, 2073/1421, p. 30 y doc. 13, 10/5/1423, p. 35, respectivamente. 
concejo de Ávila, que había prohibido la saca, intentando que se les permita comprar pan. La respuesta abulense es ilustrativa de la generalización del problema: explican que deben negarse a tal pedido por

la grant neçesydat en que estavan y están por faltaçión e mengua de pan, e en conmo en Toledo e en Salamanca e en Segovia e en Arévalo e en todos los otros lugares comarcanos desta çibdat, donde essa e su tierra se solían acorrer en el tienpo de la carestía, conmo agora es, estava e está vedada la saca, e conmo esta çibdat e su tierra está muy necesitada de pan... ${ }^{35}$

La carestía, por lo tanto, opera como trasfondo y de manera indisociablemente unida a la alteración política de los canales de la circulación. Podemos especular sobre si estas medidas potenciaron o mitigaron la escasez, pero difícilmente podemos negarlas como elementos constitutivos de la coyuntura. En resumen, en estructuras concejiles fuertemente dependientes del abasto externo, cualquier alteración de los canales habituales de aprovisionamiento puede tener efectos inmediatos sobre la subsistencia de los habitantes del lugar, determinando, de esta manera, el impacto concreto que tienen las variaciones más o menos pronunciadas del producto agrario.

Por último, es innegable que ciertas referencias documentales permiten suponer que en algunas situaciones de carestía los problemas de la circulación y los intercambios desempeñan un papel protagónico y hasta exclusivo, como se explica en la siguiente petición de las Cortes de 1425:

por quanto en muchas çibdades e villas e logares delos mis rregnos se auian entremetido e entremetian muchas personas cabdalosas aconprar pan, asi enlas çibdades e villas e lugares onde beuian commo en sus comarcas, e quelo ençerrauan e esperauan alo rreuender a muchos mayores preçios delo quelo conprauan, delo qual se rrecresçia mucha carestia enel pan, e grand danno alos pueblos. $^{36}$

Esta denuncia modélica sobre el acopio especulativo de bienes de subsistencia, para un año del que no tenemos noticias especialmente alarmantes sobre el rendimiento de las $\operatorname{cosechas}^{37}$, explica la importancia que pueden tener los derechos desiguales de apropiación y nos aproxima a las situaciones destacadas por el modelo del entitlement approach. En particular, puede ocurrir que, como señalara

\footnotetext{
35 Mombeltrán, doc. 16, fines de 1423, p. 42.

${ }^{36}$ Cortes, III, 1425, pet. 34, p. 73; véase también idem, 1462, pet. 11; Cortes, IV, 1476, pet. 4; 1480, pet. 52. En Madrid se ordena realizar una pesquisa por todos los lugares de la tierra del pan questa conprado adelantado e a que preçios y lo enbarguen y trayan la pesquisa; MILLARES CARLO, A. y ARTILES RODRÍGUEZ, J., Ayuntamiento de Madrid. Archivo de Villa: Libro de acuerdos del concejo madrileño, 1464-1600, Madrid, 1932, tomo II, 19/8/1491, p. 284.

37 Los primeros dos o tres años de la década de 1420 parecen haber sido problemáticos, como se muestra en el caso anteriormente citado del conflicto entre Mombeltrán y Ávila; véase también SÁNCHEZ BENITO, “Coyuntura económica», p. 350-1. Pero para 1424/1425 no hemos encontrado menciones especiales a problemas climáticos o malas cosechas.
} 
Amartya Sen, los productores directos de bienes de subsistencias sean, paradójicamente, los que vean más entorpecido su acceso a los mismos. En las Cortes de 1433 se denuncia que los pecheros, por verse obligados a vender su producción adelantada mente... a tan pequennos preçios se precipitan en una situación de miseria, puesto que sus esquilmos no abastan despues a pagar las tales debdas, segund los dichos tan pequennos preçios en que los venden ${ }^{38}$. Condiciones estrictamente sociales, entonces, generan situaciones de alta vulnerabilidad para los productores menos favorecidos. Sobre ellas podrán o no actuar luego problemas derivados de la esfera de la producción, pero en cualquier caso estos últimos no pueden ser considerados una causa primaria o suficiente.

Además de estos casos donde priman las prácticas especulativas, la relevancia prioritaria de los canales de la circulación en la generación de situaciones de escasez también se verifica en otros escenarios. La fragilidad de las condiciones del abastecimiento de bienes básicos se manifiesta también como efecto involuntario de decisiones políticas que persiguen otros objetivos. La creación de mercados francos, por ejemplo, parece haber provocado serios problemas al desarticular los circuitos comerciales existentes. Los procuradores señalan que a consecuencia de la proliferación de exenciones de alcabala

quelas viandas e cosas que se solian vender enlas mis çibdades e villas e logares para prouision e mantenimiento dellas, non se venden commo se solian vender, por quelas llieuan a los dichos mercados e ferias por rrazon dela dicha franqueça, e se encareçen, e non se fallan a conprar, e van a las conprar alas dichas ferias y mercados, mucho mas caras delo que solian valer ${ }^{39}$

Recapitulando, las observaciones anteriores apuntan a señalar que la dicotomía teórica entre la producción como lo natural y la circulación como lo social debe ser flexibilizada o, mejor aún, no debiera llegar a cristalizar como tal. El registro histórico y la reflexión historiográfica permiten afirmar que tanto la producción como la circulación presentan características histórico-sociales, y que ambas desempeñan papeles relevantes en las coyunturas de carestía, aún cuando su peso relativo pueda ser variable en cada caso. Ello se comprende si recordamos que, en definitiva, la reproducción social es un movimiento caracterizado por la unidad e interdependencia de la producción y la circulación. La producción no sólo genera el objeto de la circulación sino que también condiciona, como hemos visto, su forma. Pero la circulación también supone la distribución desigual de los recursos sociales, lo que a su vez condiciona la forma del ciclo productivo ${ }^{40}$. En el caso que nos ocupa, además, la coexistencia de modos de circulación extra-económicos (los derechos feudales de apropiación) y mercantiles complejiza el panorama y exige pres-

38 Cortes, III, 1433, pet. 34, p. 180.

39 Cortes, III, 1430, pet. 25, pp. 89-90.

40 MARX, K., «Introducción general a la crítica de la economía política (1857)», en IDEM, Contribución a la crítica de la economía política, México, Siglo XXI, 1980. 
tar una atención especial a la manera en que actúan sobre un sistema productivo indudablemente sometido a los avatares climáticos y naturales.

En este sentido, la discusión sobre los orígenes de la crisis de subsistencia de la primera década del siglo XVI en la Corona castellana brinda un ejemplo especialmente interesante.

\section{CAUSAS DE LA CRISIS DE PRINCIPIOS DEL SIGLO XVI EN CASTILLA: EL OBISPADO DE ÁVILA}

Una aproximación a la crisis de subsistencia que se registra en el reino castellano en la primera década del siglo XVI permite ilustrar algunas de las ideas recién expuestas. El episodio es inusual por su extensión geográfica, aunque ese mismo rasgo impulsó la intervención monárquica y concejil gracias a lo cual contamos con registros documentales que permiten vislumbrar la evolución de la coyuntura. Resulta especialmente importante prestar atención a lo acontecido en los primeros años de la década inicial del siglo XVI, para indagar en los orígenes de la coyuntura y en la validez de las explicaciones discutidas más arriba. Por ello, el análisis que sigue se centra en el primer quinquenio del siglo y en el obispado de Ávila, de donde ha sido publicada en los últimos años documentación abundante y continua.

Las causas de la crisis todavía son confusas y han dado lugar a distintas interpretaciones por parte de los investigadores en lo que hace a los años que van hasta mediados de la década de 1500, momento a partir del cual la escasez objetiva fruto de la mala cosecha se torna evidente. Algunos autores señalan que la crisis agraria ya estaba presente en los años 1501 y 1502. Estaríamos entonces ante una coyuntura básicamente inteligible a partir del modelo clásico, basado en la producción ${ }^{41}$. La tasa regia de precios del grano de fines de 1502, sobre la que hablaremos más adelante, se explicaría por este motivo. Por contraste, otros investigadores se inclinan por considerar que los rendimientos de las cosechas sólo presentan dificultades a partir de 1504 o 1505, por lo cual el origen de la coyuntura y la propia existencia de la tasa de 1502 deberían explicarse de otra manera ${ }^{42}$. Las alteraciones en la circulación y en los derechos de apropiación diferencial destacados por el enfoque de Amartya Sen (o incluso las causas políticas más generales que postula la propuesta de Stephen Devereux) serían entonces más aptas para dar cuenta de la

41 GIBSON, C., «An Historical Event and its Interpretation: The Castilian Grain Crisis of 1506-1507», Social Science History, Vol. 2, № 2, 1978. GONZÁLEZ GÓMEZ, «Producción y precios», p. 132, señala el año 1501 como uno de los peores desde mediados del siglo anterior en cuanto a volumen de la producción, aunque sólo 1506 figura entre los años de precios más altos (p. 135). CASADO ALONSO, «Producción agraria», p. 88, también registra un pico de precios en 1506, pero no presenta evidencias sobre baja de la producción. GONZÁLEZ JIMÉNEZ, «Las crisis cerealistas», pp. 296-7, señala como años de carestía todo el período 1502-1508.

42 YUN CASALILLA, Crisis de subsistencias, pp. 63 ss. 
situación. Oliva Herrer, por ejemplo, es categórico respeto de que la tasa de 1502 no sólo es anterior a la crisis agraria, sino que incluso es responsable de la coyuntura, que luego se agrava por la debacle productiva ${ }^{43}$.

La documentación que hemos consultado permite marcar algunos matices respecto de estas visiones. En nuestra opinión parece claro que, en efecto, la crisis productiva, de forma profunda y general, no hace su aparición hasta el año 1504 o 1505, aunque sí hay que tener en cuenta la existencia de coyunturas locales críticas y de rendimientos mediocres crónicos en los años previos. Una denuncia de 1502 sobre abusos en el cobro de los votos de Santiago, tributo que se paga en producto, indica que en Cáceres en ese momento se pretende cobrar las cantidades que no habían sido recaudadas en años anteriores porque por cabsa del anno, que a seydo muy esterile el pan vale dos tanto e más que quando ellos heran obligados a pagar ${ }^{4}$. Las referencias de este tipo, sin embargo, son efectivamente aisladas y no indican la existencia de una crisis de producción generalizada en los primeros dos o tres años del siglo.

La documentación abulense en el Registro General del Sello correspondiente al período de 1500 a 1504 permite un seguimiento bastante preciso de la situación en ese obispado ${ }^{45}$. Con anterioridad a la tasa regia de diciembre de 1502, la situación parece bastante normal y apenas hay indicios de problemas localizados. Las quejas sobre recaudación de tributos en especie, a diferencia de lo que acabamos de ver en Cáceres, no contienen menciones especiales a la escasez o el aumento de precios ${ }^{46}$. Se con-

43 OLIVA HERRER, H. R., «Reacciones a la crisis de 1504 en el mundo rural castellano», en OLIVA HERRER y BENITO MONCLÚS (eds.), Crisis de subsistencia, p. 259. SÁNCHEZ BENITO, "Crisis de abastecimiento», p. 282, señala con más cautela la mala cosecha pero también el movimiento especulador desde 1502-3.

44 GARCÍA OLIVA, M. D., Documentación histórica del Archivo municipal de Cáceres (1475-1504), Salamanca, 1988 (en adelante: Cáceres), doc. 206, 30/6/1502, p. 401; en doc. 205, 10/6/1502, se dice que la renta no se ha recaudado por seis o siete años.

45 GARCÍA PÉREZ, J. J., Documentación Medieval Abulense en el Registro General del Sello, Vol. XVI (4-I-1500 a 23-XII-1500), Ávila, 1998; LÓPEZ VILLALBA, J. M., Documentación Medieval Abulense en el Registro General del Sello, Vol. XVII (4-I-1501 a 24-XII-1501), Ávila, 2004; GARCÍA PÉREZ, J. J., Documentación Medieval Abulense en el Registro General del Sello, Vol. XVIII (1-I-1502 a 30-X-1502), Ávila, 2007; LÓPEZ VILLALBA, J. M., Documentación Medieval Abulense en el Registro General del SeIlo, Vol. XIX (3-XI-1502 a 19-V-1503), Ávila, 2007; LADERO QUESADA, M. F., Documentación Medieval Abulense en el Registro General del Sello, Vol. XX (22-V-1503 a 30-XI-1503), Ávila, 2007; LUIS LÓPEZ, C., Documentación Medieval Abulense en el Registro General del Sello, Vol. XXI (1-X-1503 a 30-IV1504), Ávila, 2007; DEL SER QUIJANO, G., Documentación Medieval Abulense en el Registro General del Sello, Vol. XXII (3-V-1504 a 23-XII-1504), Ávila, 2010. Se cita en adelante como Registro Gral. del SeIlo, seguido del número del volumen correspondiente.

${ }^{46}$ Registro Gral. del Sello XVII, docs. 14, 15, 25, 26, 46. Una excepción podría ser la queja elevada por Bonilla de la Sierra donde se afirma que no recaudan el pan syete o ocho años de que vale barato e que, después del dicho tienpo, se lo demandáys todo junto en los años caros, Registro Gral. del Sello XVI, doc. 52, 16/9/1500, p. 110; pero esta es una formulación estandarizada que se encuentra repetida en otros documentos y no una mención precisa sobre la situación puntual; por ejemplo, HERNÁNDEZ PIERNA, J., Documentación medieval abulense en el Registro General del Sello, vol. XI (3-I-1495 a 13XII-1495), Ávila, 1995, doc. 85, 28/7/1495 y doc. 57, 14/4/1495; GARCÍA PÉREZ, J. J., Documentación medieval abulense en el Registro General del Sello, vol. XV (18-I-1499 a 24-XII-1499), Ávila, 1996, doc. $44,6 / 7 / 1499$. 
servan algunas denuncias sobre la veda de saca de pan que implementan ciertos concejos, pero esta era una práctica muy extendida más allá de los momentos de carestía (como también lo es el otorgamiento de licencias en contrario) ${ }^{47}$. En algunos casos, como en los reclamos de Segovia, Madrigal y la aldea de Arenas, se aclara que son importadores permanentes de grano ${ }^{48}$. Los reyes, por su parte, ordenan que se levanten las vedas y que se constriña a los que tienen existencias de grano a que lo vendan a los preçios que vale ${ }^{49}$, lo que nos indica que, si bien ya se presumía la existencia de prácticas de acopio, los precios vigentes no eran aún problemáticos. Esto último se confirma por el pedido que hace Bonilla de la Sierra para que se le permita recaudar por vía de repartimiento 20.000 mrs. que necesitaba para gastos concejiles, puesto que no tenía reservas salvo çierto pan de los propios e que sy se oviese agora de vender que sería a menos preçios ${ }^{50}$. Por un documento posterior también sabemos que en 1501 el concejo de Cardeñosa compró a crédito 350 fanegas de cereal por un valor de 16.000 mrs., es decir, menos de 46 mrs. la fanega ${ }^{51}$.

En la documentación abulense hemos encontrado sólo dos menciones inequívocas a problemas en la producción para los años inmediatamente anteriores a la tasa de fines de 1502. En la primera, el concejo de Martín Muñoz de las Posadas, aldea de Segovia, dice que el año pasado se apedrearon los panes e las viñas e que este presente año asý mismo diz que se elaron las viñas e que en el dicho logar non ay pan $^{52}$, declaración hecha a los efectos de evitar que los reyes manden aposentar sus tropas en el lugar, por lo que podemos suponer cierto grado de exageración al respecto ${ }^{53}$. En la segunda, el concejo de Cabezas del Pozo, aldea de Arévalo, solicita que se le conceda un plazo de espera por deudas originadas en la compra al fiado de pan y de ciertas bestias a cabsa de la mucha neçesidad que tovieron de pan el año pasado ${ }^{54}$. Esto es todo lo que puede citarse como prueba positiva de la existencia de problemas en el ámbito de la producción.

47 Por ejemplo, en junio de 1497, mandaron vedar la saca del pan con las condiciones acostunbradas... salvo a aquellos a quien fuere dada liçençia, DEL SER QUIJANO, G., Documentación del Archivo Municipal de Ávila, vol. V (1495-1497), Ávila, 1999, pp. 147-8.

48 De Segovia se dice que a causa de la dicha çibdad e su tierra ser estérile de pan, diz que tienen nesçesidad de lo traer de otras partes, Registro Gral. del Sello XVII, doc. 103, 23/7/1501, pp. 242-3. De Madrigal, que en la dicha villa ay de contino grand mengua de pan... porque los vezinos de ella tyenen sus fazyendas en vino, Registro Gral. del Sello XVII, doc. 114, 11/9/1501, p. 263. De Arenas, que la dicha villa es tierra muy estérile de pan, que non se puede mantener synon del acarreo, Registro Gral. del Sello XVIII, doc. 68, 15/7/1502, p. 156. Otros reclamos similares en Registro Gral. del Sello XVIII, doc. 2426/4/1502 y doc. $92,2 / 9 / 1502$.

49 Registro Gral. del Sello XVII, doc. 134, 9/12/1501, p. 302; también idem, doc. 136, 24/12/1501.

50 Registro Gral. del Sello XVII, doc. 105, 29/7/1501, p. 246.

51 Registro Gral. del Sello XXII, doc. 129, 6/11/1504, donde piden permiso para recaudar por sisa o repartimiento para ésta y otras deudas; aunque no sepamos de qué cereal se trata, el precio es bajo incluso si fuera todo cebada: en diciembre de 1502, la tasa oficial será de $110 \mathrm{mrs}$. para el trigo y 60 para la cebada (véase infra).

52 Registro Gral. del Sello XVII, doc. 59, 19/4/1501, p. 160.

53 Las tropas habían estado asentadas en Arévalo por un tiempo, lo que originó las quejas habituales; finalmente se instalaron en Martín Muñoz de las Posadas, aunque un tiempo después se mandó que una parte de ellas se trasladara a otro lado; véase Registro Gral. del Sello XVII, doc. 12, 4/2/1501; doc. 51, 22/3/1501 y doc. 70, 30/4/1501.

54 Registro Gral. del Sello XVIII, doc. 111, 6/10/1502, p. 243. 
Sin embargo, esto no supone que la situación del abasto local fuera holgada. Las actas del concejo abulense registran algunos indicios alarmantes, aunque todavía esporádicos. En mayo de 1501 se pide que no se concedan más licencias de saca por que el pan se va encareçiendo e darán ocasión a que suba más; hacia noviembre, ante la debilidad de la oferta, se manda que compelan para ello a los que lo tienen para que lo vendan ${ }^{55}$. También sabemos que en junio de 1502 se le pagó a un vecino el salario correspondiente por haber ido a Oropesa y a otras partes a buscar pan para el basteçimiento desta çibdad ${ }^{66}$. Estas menciones permiten pensar que la fragilidad del abasto ya empezaba a insinuarse aún antes de que hubiera problemas climáticos generalizados que provocaran bruscas caídas de los rendimientos. En este plano, es probable que esa fragilidad estructural se vinculara más a las características de la apropiación y el usufructo de la tierra que a la meteorología. Distintas referencias al hambre de tierras y a la ocupación ilegal de pastos y dehesas por parte de los labradores apuntan en este sentido ${ }^{57}$. La orientación ganadera de los propietarios acomodados y el desplazamiento de los pequeños agricultores parece haber generado una situación de inestabilidad crónica que, a nuestro juicio, opera como sustrato fundamental en toda la coyuntura, situación en la cual una reducción moderada de los rendimientos impacta de forma potenciada, desatando la espiral clásica de carestía y especulación.

A partir de esta evidencia, creemos que debe darse crédito a las interpretaciones que señalan, como hemos visto, que la crisis se inicia por problemas en el ámbito de la distribución de la riqueza social. Aun cuando se recuerde la existencia de dificultades climáticas localizadas, esta interpretación inspirada en el enfoque de Sen parece la más adecuada ${ }^{58}$. El documento de la tasa regia que hemos mencionado, de hecho, sostiene que el origen de la escasez se encuentra en el acopio especulativo. En efecto, a fines de 1502 los Reyes Católicos establecen precios máximos para los próximos diez años para el trigo, la cebada y el centeno. Según la monarquía, la carestía se debe a que los labradores debieron vender su producción para pagar deudas pasadas y rentas, por lo que el grano está en poder de recatones e personas que no tienen nesçesidad e han guardado e guardan el dicho pan $^{59}$. Los precios establecidos, por su parte, eran lógicamente inferiores a los

55 MARTÍN GARCíA, Resumen de Actas del Concejo de Ávila, Tomo I (1501-1521), Ávila, 2009, reuniones del 15/5/1501 y del 13/11/1501, pp. 26 y 42, respectivamente.

56 IBÍDEM, reunión del 25/6/1502, p. 55.

57 ... muchos labradores tornan a entrar e ocupar los dichos términos e pastos comunes, IBÍDEM, reunión del 9/11/1501, p. 41. Ya hemos mencionado el caso del lugar de Riofrío, especialmente gráfico al respecto. El lugar de Cebreros pide ampliación de sus términos para poder labrar por pan porque tenían muy poco, pero ello no se debe a la carestía sino, por el contrario, al crecimiento exponencial de los vecinos del lugar en las últimas dos o tres décadas, siendo agora çerca de dies partes más que entonçes, Registro Gral. del Sello XX, doc. 27, 27/6/1503, pp. 86-7. Como veremos más adelante, estas menciones también refutan que la tasa de precios hubiera impactado negativamente en la esfera de la producción.

58 Entendiendo dicho enfoque, como ya hemos señalado, en el amplio sentido en que lo postulara su autor, como problemas originados en los derechos desiguales de apropiación tanto de los medios de producción como del producto. 
vigentes en muchos lugares, pero una somera comparación permite afirmar que tampoco se los puede considerar arbitrarios ${ }^{60}$. Adicionalmente, la monarquía establece la obligación de vender al precio oficial para aquellas personas que poseyeran existencias superiores a sus necesidades de consumo ${ }^{61}$ y recuerda las disposiciones vigentes sobre la libre circulación interna y la prohibición de exportación fuera del reino ${ }^{62}$. También se permite la existencia de precios diferenciales para los lugares de acarreo ${ }^{63}$ y una cierta variación estacional en el precio del pan cocido ${ }^{64}$. Posteriormente se manda recolectar información sobre la producción de los últimos años con el objeto de prevenir la aparición de carestías locales, porque sy paresçiere que hay alguna falta de pan con tienpo se provea y remedie de otras partes de nuestros reynos ${ }^{65}$. La represión que se ejerce frente a las prácticas especulativas no supone un simple desconocimiento por parte del poder respecto del funcionamiento del mercado, sino un intento por limitar lo que se consideran distorsiones artificiales del mismo.

Por lo tanto, la crisis en la producción, entendida como una caída de los rendimientos por causas naturales, fue precedida y acompañada por fenómenos de apropiación desigual y prácticas especulativas que dificultaron el acceso de los sectores más desprotegidos a los medios de producción y a los bienes de consumo existentes. La situación de pauperización y consiguiente endeudamiento de los productores, un fenómeno de creciente importancia desde la baja Edad Media, conlleva una reconfiguración de la organización productiva y distributiva de las comunidades. Lejos de constituir una causa exógena autosuficiente, la alteración climática operará sobre este contexto social.

59 SÁNCHEZ RUBIO, M. A., Documentación medieval. Archivo Municipal de Trujillo (1256-1516), Parte II, Cáceres, 1994 (en adelante, Trujillo, II), doc. 215, 23/12/1502, p. 55. La tasa se reproduce también en Registro Gral. del Sello XIX, doc. 46, 23/12/1502. La comenta HAMILTON, E. J., El tesoro americano y la revolución de los precios en España, 1501-1650, Barcelona, Crítica, 2000, pp. 258 ss.

${ }_{60}$ La tasa establecía un precio máximo de $110 \mathrm{mrs}$. para la fanega de trigo, mientras que, por ejemplo, una ordenanza sin fecha exacta pero seguramente de finales del siglo XV, de Cáceres, menciona como un parámetro medio un precio de 60 mrs.: Cáceres, doc. 138, s/f, p. 276. Según Yun Casalilla, cuando la situación se normalizó a finales de la década de 1510, en Córdoba la fanega de trigo no superaba los 50 mrs., Crisis de subistencia, ob. cit., p. 78. No puede suponerse, por lo tanto, que el precio de la tasa simplemente ignorara la coyuntura inflacionaria.

61 Véase sobre esto Registro Gral. del sello XIX, doc. 88, 2/5/1503; y Trujillo, II, doc. 230, 2/5/1503.

62 Sin embargo, permiten vender grano al reino de Valencia, pagando los derechos correspondientes, a pesar de la pragmática, salvo que ellos se encuentren al sur del Tajo; Registro Gral. del Sello XIX, doc. $55,24 / 1 / 1503$.

63 ... lo pueda vender e venda a los presçios de la dicha nuestra premátyca, con más por el acarreo dos mrs. de cada legua por cada fanega de trigo, Cáceres, doc. 224, 28/7/1504, p. 451 y Registro Gral. del Sello XXII, doc. 69, 8/8/1504.

64 Por cédula real de marzo de 1504 se permite que hasta agosto la libra de pan cocido se pueda vender a 5 blancas (es decir, 2,5 mrs.) en lugar de 2 mrs. como estaba dispuesto, Trujillo, II, doc. 243, 20/3/1504 (el precio original en Trujillo, II, doc. 229, 2/5/1503); también contiene disposiciones sobre el precio de acarreo. También el harina debe venderse al precio del trigo mas las costas de fazer la dicha harina, Trujillo, II, doc. 216, 2/1/1503, p. 57.

65 Cáceres, doc. 222, 18/7/1504, p. 448. 
Entre fines de 1502 y los inicios de 1504, parece haber una tendencia al deterioro progresivo de la situación, con indicios de una profundización de la situación recesiva ${ }^{66}$, pero a nuestro juicio es dudoso que pueda atribuirse a la tasa de precios la responsabilidad de la coyuntura. En la documentación abulense, las referencias a la aplicación de la tasa no brindan una imagen tan negativa. En este sentido es instructivo el caso de Francisco Gómez, vecino de Martín Muñoz de las Posadas, condenado por haber vendido cebada junto con el trigo, todo ello al precio de tasa (esto es, $110 \mathrm{mrs}$. la fanega de trigo y $60 \mathrm{mrs}$. la de cebada), cuando en dicho lugar la cebada sólo costaba $45 \mathrm{mrs}$., por lo que el procurador fiscal interpreta que de hecho cargó quinse maravedís de más quantía de la tasa que el dicho trigo podía vender. El acusado, por su lado, apela infructuosamente diciendo que estaba permitido vender a 110 y $60 \mathrm{mrs}$. el trigo y la cebada, como él lo había hecho, y que además había dado al comprador plazo de seis meses para la paga ${ }^{67}$. Aunque los reyes confirman la sentencia en su contra, el pleito revela una situación ambigua, que tanto puede considerarse una violación de la tasa del trigo como un sobreprecio en la cebada respecto de su valor de mercado (un $25 \%$ inferior al de la tasa) por el carácter fiado de la operación; pero en cualquier caso no parece una situación dramática del mercado que pueda atribuirse a la tasa misma. En otra denuncia, el acusado niega haber excedido el precio oficial, $e$ que sy alguna cosa le fue dada demasiado hera por la traýda del dicho pan... porque el lo llevava a la çibdad de Toledo, lo que de hecho estaba permitido, por lo que los reyes mandan tomar declaración a los testigos que presenta ${ }^{68}$. Una denuncia más ${ }^{69}$ y algunas quejas por la actuación del juez ejecutor, Diego de Ayala ${ }^{70}$, completan el cuadro.

Estas pocas menciones a dificultades o conflictos en torno a la aplicación de la tasa de precios conviven, en el año 1503 y los primeros meses de 1504, con un incremento tendencial de las denuncias sobre vedas de saca de pan. Las violaciones a la provisión regia sobre la libre circulación son mucho más abundantes que las referidas a la pragmática de precios, lo que habla de la peculiaridad de estas economías parcialmente mercantilizadas. En mayo de 1503, Ávila pide autorización

66 Aún así hay referencias en otros sentidos. El concejo de Arenas, lugar que ya hemos visto que se abastece por el comercio, no parece aún demasiado preocupado por cuidar a sus proveedores: a mediados de 1503 se denuncia que ha hecho una ordenanza prohibiendo llevar madera a Talavera, comercio en el cual suelen e acostumbran llevar retorno de pan para sus mantenimientos, según parece con el fin de favorecer a los vecinos ricos del lugar, que compráys las dichas maderas de la gente pobre por baxos preçios e las vendes después como queréys, Registro Gral. del Sello XX, doc. 35, 6/7/1503, p. 101.

67 Registro Gral. del Sello XX, doc. 30, 30/6/1503, p. 91.

68 Registro Gral. del Sello XX, doc. 57, 24/7/1503, p. 140.

69 Registro Gral. del Sello XXI, doc. 8, 13/10/1503.

70 El consejo de Ávila denuncia que el juez hace pesquisas a los vecinos syn los llamar, ni oyr, ni declarar, ni publicar las personas e testigos de quien os ynformáys y queréys ynformar, e syn dar copia ni traslado a ninguna de las partes contra quien proçedéys, e que tampoco los llamáys para oyr las sentençias que dáys, ni se las notificáys ni fazéys notificar, Registro Gral. del Sello XX, doc. 54, 20/7/1503, p. 134. El plazo para hacer pesquisa se le había prorrogado un tiempo antes: Registro Gral. del Sello XX, doc. 31, 30/6/1503. Véase también Registro Gral. del Sello XXI, doc. 16, 23/10/1503. 
para tomar «tanto por tanto» las 6.000 fanegas de trigo que Toledo tenía compradas en su jurisdicción, viendo la nesçesidad que avía en la dicha çibdad, agravada por el momento del año ${ }^{71}$. Unos días más tarde, es necesaria una provisión regia para garantizar a un comerciante toledano que podrá trasladar libremente desde Ávila 100 fanegas de trigo para la provisión de su casa ${ }^{72}$. Las autoridades concejiles se ensañan especialmente con el grano de las rentas de propietarios ajenos a su jurisdicción: en Arévalo, por ejemplo, se hace un registro de todas las existencias y se manda que no pagasen dello a las personas de quien tenían las dichas rentas que tenían fuera de la jurisdiçión ${ }^{73}$. Los casos se multiplican en los primeros meses de $1504^{74}$; lo que provoca las dificultades habituales para aquellos lugares que normalmente se abastecen de afuera ${ }^{75}$; incluso quienes logran comprar y sacar el pan son detenidos en los caminos, sus cargas son confiscadas e aún maltratan a los que lo llevan ${ }^{76}$. No es improbable que estas acciones incluyeran la participación popular en las requisas. Las vedas eran perjudiciales para los mercaderes, para los rentistas y aún para los lugares que se abastecían de acarreo, pero sin duda contaban con el respaldo activo de las poblaciones que veían disminuidas sus provisiones en los años de rendimientos mediocres.

Todo ello parece indicar una situación problemática vinculada principalmente a la distribución de las menguadas existencias disponibles, a partir del incremento de las (por otro lado habituales) medidas de veda de saca. Antes que el saldo dinerario positivo que produciría la saca, los concejos priorizan el saldo material positivo que produce la veda. En marzo de 1504, Mombeltrán, que también dice ser muy estérile de pan, denuncia que cuando van a buscarlo a otros lados non ge lo dexan sacar, poniendo guardas a las puertas e a los caminos, pero en este caso la usual condena regia a la veda adquiere un tono de mayor cautela: ordenan que se les permita sacar grano pero sólo de lo que sobrare una vez garantizado el abasto de los lugares respectivos de aquí a la cosecha del pan nuevo ${ }^{77}$. Los parámetros de este cambio de actitud de la monarquía habían sido establecidos unos días antes, en la orden del 15 de marzo de 1504, en la que se manda a distintas villas y lugares del reino que se haga pesquisa del pan existente; se apremie a vender al precio de tasa lo que exceda las necesidades de los particulares hasta la nueva co-

\footnotetext{
71 Registro Gral. del Sello XIX, doc. 89, 4/5/1503, p. 267; se les concede que puedan tomar la mitad y que liberen la otra mitad para Toledo.

72 Registro Gral. del Sello XIX, doc. 92, 8/5/1503, p. 272.

73 Registro Gral. del Sello XX, doc. 65, 2/8/1503, p. 156.

74 Registro Gral. del Sello XXI, doc. 60, 23/1/1504; doc. 116, 24/3/1504; se pide sacar 40 fanegas del lugar de Cantaracillo, habiendo ya dejado otras 60 para provisión local, doc. 118, 28/3/1504; el obispo de Ávila pide sacar 150 fanegas de las 700 que tenía en Madrigal, doc. 127, 2/4/1504.

75 Este último es el caso de Otero de los Herreros, tierra de Segovia, a cabsa de ser el dicho lugar de syerra e muy estérile, Registro Gral. del Sello XXI, doc. 111, 23/3/1504, p. 214; caso idéntico al de la aldea de Las Vegas, doc. 113, 23/3/1504. También se impide a un particular sacar grano de una aldea de Arévalo en doc. 95, 7/3/1504.

76 Registro Gral. del Sello XXI, doc. 112, 23/3/1504, p. 216; doc. 135, 18/4/1504; Registro Gral. del Sello XXII, doc. 4, 11/5/1504.

77 Registro Gral. del Sello XXI, doc. 110, 23/3/1504, pp. 213-4.
} 
secha; se compre a costa de los propios si se estima que no alcanzará; se recaude por vía de sisa en otros artículos si no hay dinero de propios en el lugar; y se tomen préstamos forzosos de los vecinos hasta tanto se recaude la sisa ${ }^{78}$. Esto hace pensar que los meses de «soldadura» del año agrícola se presentaban como problemáticos. Aunque todavía se supone que hay asaz abasto de pan y que el problema principal radica en que muchas personas tyenen el pan escondido e non lo quieren vender con pensamiento que lo han de vender a mayor preçio de lo que agora vale ${ }^{79}$, el conjunto de medidas mencionado indica que estamos frente a una situación de escasez en el momento más crítico del año agrícola y que no hay certeza en cuanto a que las provisiones alcancen hasta la nueva cosecha. Pero incluso en este escenario las prácticas de acumulación denunciadas por la monarquía tienen una incidencia real. En mayo de 1504, en San Esteban de Zapardiel, se manda forzar a un vecino a que venda 250 fanegas de trigo que tenía acumuladas, puesto que se negaba a hacerlo salvo dándole heredades e tierras en pago dello, e no de otra manera, mención ejemplar por su crudeza en cuanto al efecto de mediano plazo sobre la estructura social que podía tener la crisis de subsistencias ${ }^{80}$.

El deterioro progresivo de la situación también se refleja, en la documentación abulense, en el incremento de los pedidos de espera realizados por deudores que no están en condiciones de cumplir sus obligaciones. En algunos casos, ciertamente, no se trata de campesinos arruinados por la situación sino de operaciones de gran envergadura ${ }^{81}$. Un deudor, Pedro Dávila, vecino de Sinlabajos, a quien se concede espera por diversas deudas, es también denunciado por haber cobrado indebidamente ciertos bienes y servicios a los aldeanos de los cuales era acreedor ${ }^{82}$. Otro caso, finalmente, refiere a un hidalgo empobrecido que hubo de comprar a crédito caballo y arnés por valor de $9.000 \mathrm{mrs}$. para servir en la guerra con Francia $^{83}$. Pero aun cuando un escrutinio más exigente nos lleve a excluir estos y otros ejemplos dudosos, entre los últimos meses de 1503 y los primeros de 1504 se registra una treintena de casos de deudores insolventes, cuya situación en ocasiones se vincula explícitamente a la crisis agraria ${ }^{84}$.

78 Registro Gral. del Sello XXI, doc. 106, 15/3/1504.

79 Ibídem, p. 205. También Trujillo, II, doc. 245, 23/3/1504. Todavía en julio de 1504 se denuncian muy grandes exçesivos presçios syn en verdad aver nesçesidad alguna de trigo, Trujillo, II, doc. 259, 27/7/1504, p. 99. Véase también Cáceres, doc. 223, 27/7/1504.

80 Registro Gral. del Sello XXII, doc. 16, 26/5/1504, p. 59.

81 Como es el caso de Pedro Lozano, deudor de 100.000 mrs. de rentas, Registro Gral. del Sello XXI, doc. $98,9 / 3 / 1504$; o de una operación confusa, que parece una estafa comercial, por valor superior a $50.000 \mathrm{mrs}$, que se consigna en doc. 90, 1/3/1504 y doc. 108, 22/3/1504.

82 Registro Gral. del Sello XX, doc. 121, 18/9/1503; Registro Gral. del Sello XXI, doc. 38, 23/11/1503 y doc. $39,23 / 11 / 1503$.

83 Registro Gral. del Sello XXI, doc. 87, 29/2/1504.

84 Es el caso, por ejemplo, de los siguientes documentos: Registro Gral. del Sello XX, doc. 110, 11/9/1503; Registro Gral. del Sello XXI, doc. 1, 2/10/1503; doc. 31, 14/11/1503; doc. 56, 14/1/1504; doc. 84, 24/2/1504; doc. 101, 10/3/1504; doc. 136, 20/4/1504. El incremento es notorio respecto a la documentación de los años previos; en la Introducción de ambos volúmenes, los editores destacan esta proliferación de cartas de espera. 
La coyuntura sigue siendo crítica en lo que resta de 1504, lo que indica que la cosecha de ese año no fue suficiente para revertir la carestía en los dos aspectos que ya sabemos que la caracterizan: debilidad del abasto y especulación. En algunos lugares encontramos menciones explícitas a problemas climáticos. Honcalada, en tierra de Arévalo, solicita ser eximida de su obligación de mandar provisiones a la Corte porque diz que se avía apedreado lo más del pan e vino que avía en el dicho logar, por lo que non tenían qué comer nin senbrar ${ }^{55}$. En San Esteban de Zapardiel, también lugar de Arévalo, un campesino se declara incapaz de responder por una deuda menor a cabsa que se le apedrearon las viñas ${ }^{86}$. En julio de ese año, el lugar de Grajos, por ser el tienpo tan estérile e tan nesçesitado, pide autorización para arrendar sus términos al ganado de afuera, a lo que se oponen los propietarios de ganado locales ${ }^{87}$.

En la segunda mitad de 1504, dos nuevas menciones documentales vinculan la carestía a la tasa de precios y en ambas se evidencia que también intervienen otras variables. En el primer caso, el concejo de Mombeltrán, que ya sabemos que se abastece vía comercio y que además está en el paso de la ruta hacia Andalucía, dice que no puede garantizar la provisión de la villa a cavsa que no se puede vender synon conforme al preçio de la premática, por lo que pide autorización para vender el pan cocido en función del precio de compra más el costo del acarreo a razón de $2 \mathrm{mrs}$. por legua ${ }^{88}$. Tiempo antes, como hemos visto, los monarcas ya habían dispuesto al respecto que se pudiera adicionar ese importe en concepto de transporte del grano, como así también que el pan cocido se pudiera vender a un precio superior. Esto último generó que los propietarios del grano optaran por venderlo sólo cocido, contra lo cual se dispuso que las autoridades locales pusieran panaderías obligadas en cada lugar e que ninguno pueda vender pan cozido en esa çibdad synon las personas diputadas por aquel o aquellos en quien se rrematare la dicha panadería ${ }^{89}$.

Como se ve, las medidas políticas siguen apuntando a combatir distintas prácticas especulativas que potencian el efecto de los mediocres rendimientos agrarios. Esto requiere una breve reflexión. La opinión según la cual la tasa de precios empeoró la situación puede basarse en dos supuestos, a saber: que a causa de la tasa y de una menor rentabilidad esperada se redujo el área sembrada, o que a causa de los precios oficiales se incrementó el acopio. Respecto de lo primero, que supone un comportamiento capitalista de los productores, no hemos encontrado evidencia alguna: las posibilidades de la producción campesina aparecen deter-

\footnotetext{
85 Registro Gral. del Sello XXII, doc. 91, 11/9/1504, p. 190.

86 Registro Gral. del Sello XXII, doc. 149, 5/12/1504, p. 284.

87 Registro Gral. del Sello XXII, doc. 44, 11/7/1504, p. 106; se les concede autorización para ello en idem, doc. 97, 14/9/1504.

88 Registro Gral. del Sello XXII, doc. 113, 14/10/1504, p. 225.

89 Registro Gral. del Sello XXII, doc. 56, 18/7/1504, p. 125; también doc. 64, 27/7/1504 y doc. 70, 8/8/1504.
} 
minadas por factores distintos a los precios, en especial por las posibilidades de acceso a la tierra ${ }^{90}$. Respecto de lo segundo, la tasa sin duda retrajo la oferta de los sectores con capacidad de acopio, al menos en la medida en que éstos lograran eludir las pesquisas concejiles; pero de ello no se deduce que la ausencia de precios máximos hubiera mejorado la situación. Un abasto mayor en cantidad, pero a precios exorbitantes, no necesariamente constituiría una mejor opción para las poblaciones afectadas por la escasez.

En el segundo caso, que involucra una mención a la tasa de precios en la segunda mitad de 1504, el recaudador de la alcabala «de lo foráneo» en Arévalo y Santa María de Nieva, impuesto que gravaría principalmente las transacciones con grano de afuera, pide que se le condone parte de lo que debe porque a cavsa de la premática del pan conmo por aver estado nuestra Corte en Segovia e en esta villa de Medina del Campo, el grano de la comarca se ha dirigido a esos lugares ${ }^{91}$. No es clara la forma en que la pragmática de precios podría haber tenido el efecto indicado sobre la renta «de lo foráneo»: si se supone que una menor rentabilidad habría impedido la llegada del grano a Arévalo, deberíamos explicar por qué eso no impidió que fuera a Segovia o a Medina del Campo ${ }^{92}$. Además sabemos que la quiebra de un arrendador de la alcabala del pan no era un fenómeno insólito también en otras coyunturas ${ }^{93}$. Por lo demás, es cierto que la proximidad de la Corte provocó varios problemas en el abasto de la región al alterar los canales habituales de la circulación, pero esto debe atribuirse a la combinación de una demanda anómala ante una oferta debilitada y no sólo a lo segundo o a la existencia de precios máximos. En realidad los monarcas temían que, a causa de los precios oficiales, el producto dejara de fluir de Arévalo a Medina del Campo, donde estaba entonces la Corte, por lo que mandan que se garantice la provisión de 40 cargas diarias de pan cocido mayormente que somos çiertos que ovo buena cosecha en toda esta tierra ${ }^{94}$, lo que tal vez era una exageración del argumento aunque la cosecha de ese año no hubiera sido tampoco desastrosa.

90 Como hemos visto más arriba, el lugar de Riofrío hubo de recibir en plena carestía a un grupo de campesinos desarraigados por las altas rentas y la dedicación ganadera de su lugar de origen; ni bien llegados comenzaron, a despecho de la tasa, a labrar la tierra; Registro Gral. del Sello XXII; doc. 33, 5/7/1504. En un pleito con la Mesta por el sembrado de pastos, el procurador de los pecheros de Ávila defiende la ocupación de tierras baldías porque los labradores con todo lo que labran non podían coger pan para sostenerse, lo que indica que la carestía tenía causas distintas a un supuesto abandono del cultivo generado por la existencia de precios máximos; Registro Gral. del Sello XXII, doc. 145, 23/11/1504, p. 278.

91 Registro Gral. del Sello XXII, doc. 38, 9/7/1504, p. 97.

92 Puesto que incluso el precio de tasa era superior al de un año normal, no es claro en qué sentido podría haber provocado la quiebra del arrendador. En realidad, esa renta debería disminuir sobre todo en los años de buena cosecha, cuando los precios era bajos y además el abasto «de lo foráneo» sería menor por la mejora de la provisión local.

${ }_{93}$ Véase el caso del arrendador de la alcabala del pan de Ávila en los años 1495 a 1497 en Registro Gral. del Sello XXII, doc. 146, 23/11/1504.

94 Registro Gral. del Sello XXII, doc. 75, 20/8/1504, p. 164. 
El abasto de la Corte también se veía obstaculizado por las vedas ${ }^{95} \mathrm{y}$, como causa de fondo, por la pobreza campesina ${ }^{96}$, dos cuestiones sobre las que hay interesantes referencias documentales.

A juzgar por las denuncias al respecto, las restricciones concejiles a la circulación son, desde mediados de 1504, aún más abundantes que en los meses previos. Ya hemos visto que, desde marzo de ese año, la monarquía comenzó a aceptar que no se sacara lo que se estime necesario para la provisión local hasta la nueva cosecha. A partir de entonces, e incluso luego de la recolección del grano, las vedas de saca para quienes tuvieran pan de rentas o comprado se incrementan de forma exponencial ${ }^{97}$. Debemos señalar, sin embargo, que las denuncias sobre vedas no pueden considerarse meramente una función directa del resultado de la cosecha o una medida adecuada de la escasez coyuntural. Luego de dos o tres años de dificultades crónicas para garantizar un abasto adecuado a precios razonables, es entendible que las autoridades locales pusieran gran empeño en impedir que el grano saliera de sus jurisdicciones inmediatamente después de la recolección. Las restricciones a la saca formaban parte del arsenal de medidas para garantizar el abasto que desde hacía un siglo aplicaban los concejos en distintas circunstancias, y es lógico que en esta coyuntura fueran particularmente escrupulosos al respecto.

La expectativa en cuanto a que el grano recolectado, sin ser demasiado cuantioso, podía sin embargo garantizar un abasto tolerable por medio de una adecuada administración política de las existencias, se manifiesta también en las iniciativas tendentes a crear depósitos públicos. Estas alhóndigas debían almacenar grano suficiente para la provisión de dos meses al precio oficial. Tanto en Ávila como en Arévalo, se solicita que el dinero necesario se recaude por vía de empréstitos, que se devolverían al vender el pan, y no por sisa, para evitar una presión adicional sobre los precios. En esta última villa se propone, además, que la institución funcione como concesionaria del grano en poder de los particulares, lo que supone que las existencias disponibles fueran canalizadas por una concentración monopólica de las ventas que asegura la oferta a precio de tasa ${ }^{98}$. En

95 Registro Gral. del Sello XXII, doc. 77, 22/8/1504.

96 Mandan que no le tomen a un aldeano 40 o 50 fanegas de cebada para provisión de la Corte, pues las necesita para provisión de su casa et para sus mulas de labrança, Registro Gral. del Sello XXII, doc. 135, 13/11/1504, p. 262.

${ }_{97}$ Registro Gral. del Sello XXII, doc. 18, 1/6/1504; doc. 54, 17/7/1504; doc. 59, 20/7/1504; doc. 73, 16/8/1504; doc. $74,16 / 8 / 1504$; doc. $79,24 / 8 / 1504$; doc. $80,26 / 8 / 1504$; doc. 81, 28/8/1504; doc. 83, 28/8/1504; doc. 84, 30/8/1504; doc. 90, 19/9/1504; doc. 94, 13/9/1504; doc. 102, 26/9/1504; doc. 112, 11/10/1504; doc. 125, 27/10/1504; doc. 126, 27/10/1504; doc. 131, 8/11/1504; doc. 138, 15/11/1504; doc. 143, 23/11/1504; doc. 148, 5/12/1504; doc. 150, 5/12/1504.

${ }_{98}$ Respecto de Ávila, Registro Gral. del Sello XXII, doc. 106, 27/9/1504; la oposición a que se implementara una nueva sisa también se sostiene en que aún está vigente la creada para financiar la guerra con Francia, en cuya recaudación hubo además abusos considerables: se denuncia que en lugar de recaudar los 183.000 mrs. necesarios, se repartieron 290.000; idem, doc. 122, 22/10/1504. Respecto de Arévalo, idem, doc. 133, 10/11/1504. 
cualquier caso, tanto las vedas como la creación de depósitos concejiles ratifican la doble naturaleza de la carestía, vinculada a la reiteración de rendimientos mediocres pero cuyo efecto nocivo se ve incrementado por la distribución desigual del producto.

La evidencia que brindan las cartas de espera solicitadas por deudores insolventes confirma el diagnóstico. La segunda mitad de 1504 presenta una decena de ejemplos, en varios de los cuales se vincula la pobreza de los campesinos endeudados a cabsa de ser los años pasados estériles ${ }^{99}$. La cantidad de casos sigue siendo alta, pero también significativamente menor a la de los meses previos. Tal vez influya en esto una posible reducción en la oferta de crédito luego de tres años de dificultades recurrentes, pero tampoco puede descartarse un leve alivio de la situación al menos en los meses siguientes a la cosecha de julio.

La situación cambia radicalmente, sin embargo, hacia mediados de la década. En el año 1505 ya es indudable que se produce una crisis de producción aguda y generalizada en el sector primario, la cual conduce (como correctamente señalaba el modelo tradicional) a una crisis de subconsumo en el sector secundario y, finalmente, a una crisis demográfica. La secuencia ha sido detalladamente estudiada y queda por fuera de los límites de este trabajo ${ }^{100}$. En este momento realmente agudo de la coyuntura agraria, cuando la escasez objetiva de bienes se tradujo en una quiebra de la circulación mercantil, las medidas oficiales pueden haber resultado inútiles y hasta perjudiciales. Ahora sí, la desproporción existente entre las disponibilidades de grano y las necesidades de consumo constituye la base económica objetiva del descalabro de la reproducción social. En este contexto, ni siquiera las importaciones de cereal realizadas por las ciudades con fondos públicos alcanzan el efecto deseado ${ }^{101}$. La situación sólo tiende a normalizarse a partir del año 1508, como resultado de la combinación de una recomposición de la oferta por el resultado favorable de las cosechas y de un descenso de la demanda producto de la crisis demográfica anterior.

\section{CONCLUSIONES}

El análisis de la documentación abulense de los primeros años del siglo XVI nos conduce a sostener la necesidad de una concepción amplia de las crisis de subsistencia. Aunque éstas constituyen fenómenos singulares y anómalos, en los cuales sin duda intervienen factores contingentes, su comprensión requiere que se las inscriba en el contexto histórico más general. Considerarlas de esta manera, y

99 Registro Gral. del Sello XXII, doc. 21, 13/6/1504, p. 67; otros casos en doc. 71, 10/8/1504; doc. 76, 22/8/1504; doc. 78, 23/8/1504; doc. 82, 28/8/1504; doc. 98, 17/9/1504; doc. 109, 2/10/1504; doc. 123, 24/10/1504; doc. 140, 16/11/1504; doc. 149, 5/12/1504.

100 Por ejemplo, YUN CASALILLA Crisis de subsistencias, especialmente caps. II a IV.

101 IDEM, p. 76. 
no como acontecimientos meramente azarosos, obliga a una perspectiva de la totalidad que resiste todo análisis lineal. Dicho en otros términos, si bien no puede atribuirse la crisis únicamente a la esterilidad de los años, tampoco puede atribuirse únicamente al acopio, a la tasa de precios o a las medidas implementadas por los poderes políticos. No se trata de reemplazar una explicación monocausal por otra: poco avanzaría el conocimiento histórico si nos limitáramos a ello. Las valiosas modelizaciones teóricas que se han producido en los últimos años en torno al problema de las carestías deben servir, no para constreñirnos a una elección excluyente, sino para dar mayor rigor analítico a la multiplicidad de determinaciones que la historiografía ya había encontrado a partir del análisis concreto de tales coyunturas.

Sería también deseable, en un análisis de mayor envergadura que el realizado en esta aproximación, intentar calibrar los efectos de mediano plazo que produjo la coyuntura en la estructura social. Es probable que el episodio haya contribuido a la profundización de la desigualdad en los derechos de apropiación que, como hemos visto, se encuentra en los orígenes de la coyuntura. El deterioro estructural de la condición social de los productores constituye el escenario en el que opera el deterioro accidental de las condiciones medioambientales. Por esta vía, las probabilidades de repetición del ciclo se verían incrementadas. En cualquier caso, la exposición anterior tiene por objetivo fundamental llamar la atención sobre la pluralidad de factores que intervienen en la crisis, contextualizando el efecto de la disminución ocasional de los rendimientos agrarios en el cuadro más amplio de las relaciones sociales, la forma en que éstas condicionan las capacidades productivas de los actores y la consiguiente dinámica de distribución del producto social. 